A

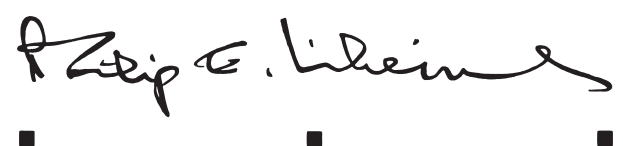

$\mathrm{B} \mathrm{O} \mathrm{O} \mathrm{K}$

The Philip E. Lilienthal imprint

honors special books

in commemoration of a man whose work

at the University of California Press

from 1954 to 1979

was marked by dedication to young authors

and to high standards in the field of Asian Studies.

Friends, family, authors, and foundations have together

endowed the Lilienthal Fund, which enables the Press

to publish under this imprint selected books

in a way that reflects the taste and judgment of a great and beloved editor. 
The publisher gratefully acknowledges the generous support of the Philip E. Lilienthal Asian Studies Endowment Fund of the University of California Press Foundation, which was established by a major gift from Sally Lilienthal. 
Ancestral Leaves 


\title{
Ancestral Leaves
}

A Family Journey through Chinese History

\author{
Joseph W. Esherick
}

\section{甲}

UNIVERSITY OF CALIFORNIA PRESS

Berkeley Los Angeles London 
University of California Press, one of the most distinguished university presses in the United States, enriches lives around the world by advancing scholarship in the humanities, social sciences, and natural sciences. Its activities are supported by the UC Press Foundation and by philanthropic contributions from individuals and institutions. For more information, visit www.ucpress.edu.

University of California Press

Berkeley and Los Angeles, California

University of California Press, Ltd.

London, England

(c) 2011 by The Regents of the University of California

Library of Congress Cataloging-in-Publication Data

Esherick, Joseph.

Ancestral leaves : a family journey through Chinese history / Joseph W. Esherick.

p. $\mathrm{cm}$.

Includes bibliographical references and index.

ISBN 978-0-520-26699-5 (cloth : alk. paper)

ISBN 978-0-520-26700-8 (pbk. : alk. paper)

1. Ye family. 2. China-Biography. 3. China-Genealogy.

4. China-History. I. Title.

CS1169.Y42 2011

929'.20951-dc22

2010024831

Manufactured in the United States of America
$\begin{array}{lllllllll}19 & 18 & 17 & 16 & 15 & 14 & 13 & 12 & 11\end{array}$
$\begin{array}{llllllllll}10 & 9 & 8 & 7 & 6 & 5 & 4 & 3 & 2 & 1\end{array}$

This book is printed on Cascades Enviro 100, a 100\% postconsumer waste, recycled, de-inked fiber. FSC recycled certified and processed chlorine free. It is acid free, Ecologo certified, and manufactured by BioGas energy. 
In memory of Ye Duzhuang 